\title{
A Review of There is No Need to Talk About This: Poetic Inquiry from the Art Therapy Studio, by Karen O. Wallace
}

\author{
Shuana Niessen \\ University of Regina
}

In her book There is No Need to Talk About This: Poetic Inquiry from the Art Therapy Studio, Karen Wallace seeks to communicate and express the "joys of living and working” (p. 125) as an art therapist who engages with clients to facilitate change through a creative process of art making. Her contemplations on her work, creatively expressed in this collection of narrative poetry, reveal her dedication to, and respect and care for, clients as they work to transform feelings of pain and loss into healing, into re-imagined, re-invented, and re-envisioned selves and worlds. Her poems are composites, "small vignettes" about her work as an art therapist and her clients explorations towards personal healing and wholeness.

Wallace views her role as an art therapist as a witness, an observer, one who, in her words, "know[s] and understand[s] that process" of change; in this role, she validates the struggles involved for clients in the process of creating something new and desired in their lives. Wallace describes her role as holding space, exploring without judgment and without attempting to fix problems, coming alongside her clients as they courageously venture out on heroic journeys to isolated inner locations, reclaiming and accepting the darkness in their lives; darkness, "which is really only the flip side" (p. 126) of light, she says. Through, "interrupting, guiding, being mindful, present with the birth of change" (p. xv), Wallace seeks to "nurture and make visible an often invisible and very charged process" (p. xv). She searches out, and creates, moments and spaces between the darkness, with the hope that in momentary and spatial relief, in the creative liminal spaces, new ideas, hopes, and changes will be born. Through her poems, readers see Wallace searching intently for the unspoken languages of symbols, images, creations, and mythologies to learn the languagess of her clients, and so, for the space of an hour, join with them in their isolated places, to dialogue there, to confirm, understand, reinforce, and validate the feelings, fears, and needs of clients.

In her art therapy practice, the change process is facilitated by art making; as clients become "engaged emotionally, mentally, and intuitively in art making, they are being mindful," connecting and becoming "available to the moment" (p. 101). The images created in art often convey thoughts and feelings that are not easily communicated through words. The inability to express pain and loss in ways that are understood creates isolation. To help alleviate the isolation of unexpressed thoughts, memories, and emotions, Wallace uses her expertise in archetypal, narrative, mythological, and symbolic meaning making, her understanding of forms, and the art making process, along with a combination of therapy techniques, to engage with clients dealing with a range of issues. Her integrative approach generally helps to create a bridge of understanding between herself and her clients. The challenge of understanding is especially expressed in her poem, "Secret Bridges," where she writes, "These are not landmarks I know./ What are the lines, shapes, and colours I can’t see?/ Teach me this language” (p. 40).

The book is organized into two groups: poems from art therapy and poems from art therapy groups. In Chapter 1, "What is Art Therapy?” Wallace begins by explaining the aims of art therapy, and attends to points of resistance, such as who can do art. "It is not about doing 'good' art, as judgement is irrelevant. All that matters is whether it gives the client a new 
perspective, helps to get in touch with feelings and or make changes” (p. 1). Trusting the process is a major theme throughout her work; one does not always understand how change happens, but one can trust in the creative process to effect change. The poetry in Chapters 2 to 7 explores a range of issues worked through in art therapy: trauma, dissociation, depression, autism, addiction, and grief. Each chapter begins with an explanation about the process involved in working through the selected issue, and introduces the included poems. Chapters 9 through 15 offer reflections on what occurs through art therapy groups. Chapter 16 explores the power of transformation in art therapy. Through art therapy, "We learn to read ourselves and find what we need to heal" (p. 117). Wallace closes with thoughts about her poems, the process work, and her hopes for the poems she has included in this collection: "My hope is that these poems express change” (p. 125).

The work is crafted for an audience that ranges from educators, teacher educators, and educational psychologists to social workers - anyone in a position of caring for others, especially young people and early childhood educators. Educators and teacher educators can benefit from reading these poems, if for no other reason than to gain sensitivity and patience in working with students. Further, because a major aspect of teaching is about observing and understanding one's students and the ability to speak the "languages" of one's students, this book is a must-read because it inspires and teaches readers to begin to watch for, and learn from, the nonverbal communications expressed by students. Behaviours and issues occur in classrooms, and educators who have the desire to hold space with their students and to gain understanding of their students so they can effectively engage with them will want to read this book. Wallace's poems demonstrate Nodding's (1984) ethic of care, of being "totally and nonselectively present to the student” (p. 180).

With only 127 pages, the book is a quick but intense read. The heights and lows of holding space with others are touchingly expressed, and may even be the beginning of a transformation in readers. 


\section{References}

Noddings, N. (1984). Caring: A feminine approach to ethics and moral education. Los Angeles, CA: University of California Press.

Wallace, K. O. (2015). There is no need to talk about this: Poetic inquiry from the art therapy studio. Boston, MA: Sense Publishers. 